\title{
The results of six-row barley breeding and the genetic origin of varieties released
}

\author{
REINO AIKASALO \\ Hankkija Plant Breeding Institute \\ SF-04300 Hyrylä, Finland
}

\begin{abstract}
This article deals with the results achieved in the breeding of six-row barley at Hankkija Plant Breeding Institute since the beginning of scientific barley breeding in the 1910s, with special reference to earliness and genetic origin of the varieties.

In Finland, barley is grown in the northern border of plant production up to the 67th parallel. Through centuries it has been an important cereal but a rapid expansion in the acreage occurred only in the mid-1970s. Today the acreage of barley is close to 700,000 hectares. Most of the crop is used for feed, the rest for malting. Adaptation to Finnish conditions, with a short growing season and acid soils, has always been the major aim in breeding.

The genetic basis for the beginning of barley breeding was locally adapted landraces which had reached Finland from east and west. The landraces showed extensive genetic variations. Through selection, a total of eight varieties - three four-row, one six-row and four two-row varieties - were developed. The most important was the extremely early variety Olli which has been an important variety not only in Finland but also in Canada.

After the variation of landraces was fully utilized, the positive characteristics of different varieties were combined by crossings. A total of eight six-row varieties have been developed since Olli. These varieties are presented in brief. It is worth noticing that all the varieties are nearly totally of Scandinavian origin.

The extremely early variety Olli is included in the pedigree of all the eight varieties released since Olli (1927). The percentage of wide crosses is minimal. However, in spite of the narrow gene pool, breeding work has produced several successful varieties which have covered a remarkable proportion of the total barley acreage. This may be a result of good adaptation of landraces and the first cultivars to the extreme weather and soil conditions prevailing in Finland.

Furthermore, although the earliness of landraces or Olli has not been exceeded, improvements in other characteristics, e.g. yielding potential, straw stiffness and malting quality, have considerably contributed to the production of Finnish barley.
\end{abstract}

Index words: Hordeum vulgare, six-row varieties, origin, morphological variation, earliness, lodging, yield breeding 


\section{Introduction}

Barley is the oldest cereal in Finland (SAULI 1927). As early as in the 14th century barley was a common crop both on the coast and in the central parts of the country. Barley was of the six-row type and it dominated field crop cultivation until the 19th century when it was replaced by rye and oats (GROTENFELT 1919). The cultivation of two-row barley began during the 18th century in the southern parts of the country. In 1920, barley covered only $5.8 \%$ of the total arable land area. Barley was also the most important cereal for human consumption.

Landraces still dominated barley cultivation in the 1920s (Sauli 1927, Pesola 1951). At this time the four-row type was the predominating type and had replaced the earlier dominating six-row type. Barley cultivation had extended from south up to the 69th parallel in the north where it was the main cereal.

The first bred varieties had spread to Finland in the early years of the 20th century, mainly from Sweden (Pesola 1951). Most of these varieties were too late, which restricted their cultivation to the southern parts of Finland (Huttunen 1955). They were of the tworow type and not adapted to extensive cultivation on acid soils. However, as a consequence of both these and new varieties resulting from domestic plant breeding, the acreage of landraces began to decrease very rapidly (Pesola 1951).

During the first half of this century the acreage of barley only slightly exceeded 100,000 hectares, covering 5-6\% of the total arable land (PAATEla 1953). Only after the second world war did the acreage of barley start to increase, exceeding 600,000 hectares in the early 1980s (Table 1), covering more than $20 \%$ of the total arable land. The total production of barley is today nearly 2 million tons, fivefold that of the early 1950 s, because also the yield per hectare has doubled during this period. Today the production of barley exceeds domestic demand and new industrial uses are being developed.

In Finland, barley is grown between the 60th and 66th parallels, which is further north than in any other country in the world. Sixrow varieties dominate today, the share of two-row varieties being approx. $25 \%$. The reason for this is that the six-row type has better adapted to our short growing season with extremely rapid growth rhythm. In these conditions the main yield component of six-row barley, the number of grains per ear, is an advantage over the tillering capacity of the tworow barley which cannot be fully utilized in our conditions (ÄYRÄVÄINEN 1976).

The earliness of the six-row type means also reliability, because the often rainy harvesting period in autumn is favourable for sprouting in the ear and may thus damage the crop (KIVI 1966). The importance of earliness in barley breeding has been emphasized by other "northern" breeders, too (GuITARD 1960, WiBERG et al. 1986).

Since 1913, both six-row and two-row barleys have been bred at the Hankkija Plant Breeding Institute. This paper presents the results of breeding of six-row barley and the genetic origin of varieties released.

\section{The genetic variation of landraces}

As in other countries, landraces were the basic material for the start of plant breeding. Land-

Table 1. The acreage of barley in Finland in 1910-1985.

\begin{tabular}{lrrrrrrrrr}
\hline Year & 1910 & 1920 & 1930 & 1939 & 1950 & 1960 & 1970 & 1980 & 1985 \\
\cline { 2 - 9 } & & & & & & & & & \\
$\begin{array}{l}\text { Acreage } \\
1,000 \text { ha }\end{array}$ & 110 & 116 & 115 & 119 & 117 & 213 & 404 & 533 & 646 \\
\hline
\end{tabular}

Official Agricultural Statistics 
races had spread to Finland from the west, although some influence of eastern (Manchurian) barleys has been reported (HoFFMANN et al. 1970). The landraces showed extensive genetic variation, which was studied in detail by J. O. Sauli, the first Head of the Hankkija Plant Breeding Institute (SAul 1927). His material consisted of more than 600 samples collected from different parts of the country, at the turn of the century and in 1919 and 1920. The material of his study also included the 1,150 selections collected from the original material. More than two thirds of this material was of the six-row and four-row types and the rest of the two-row type. The morphological variation of the material is clearly illustrated by the following taxonomic classification made by Sauli.

\section{Hordeum sativum Jess.}

\section{Subspecies}

I. Polystichum D ö 11. Multi-row type. All florets monoecious, fertile.

II. Distichum L a m. Two-row type. Median florets monoecious, fertile. Lateral florets dioeicous, having the male reproductive organs.

III. Deficiens S t e u d. Two-row type. Median florets monoecious, fertile. Lateral florets asexual, greatly reduced.

\section{Varietates}

H. sat. polystichum D ö 11.

A. Hexastichum L. Six-row type. Short, very dense ears. Mean rachis internode length $1.7-2.1 \mathrm{~mm}$. Spikelets are located in six similiar, separate rows.

B. Parallelum K c k e. Six-row, parallel type. Medium short ears, rather dense. Rachis internodes 2.1$2.8 \mathrm{~mm}$. Spikelets are located in six similiar, separate rows.

C. Tetrastichum $\mathrm{K} \mathrm{c} \mathrm{k} \mathrm{e} \mathrm{(vulgare} \mathrm{L).} \mathrm{Four-row} \mathrm{type.}$ Lax ears. Rachis internodes $2.7-4.0 \mathrm{~mm}$. The side grains overlap, giving a pseudo four-rowed appereance.

H. sat. distichum $\mathrm{L}$ a $\mathrm{m}$. and deficiens $\mathrm{S} \mathrm{t} \mathrm{e} \mathrm{u}$ d.

D. Zeocritum L. Very dense ears. Rachis internodes $1.7-2.1 \mathrm{~mm}$.

E. Erectum S c h ü b l. Medium dense, erect ears. Rachis internodes $2.1-2.8 \mathrm{~mm}$.

F. Nutans $\mathrm{S}$ c h ü b l. Nodding, lax ears. Rachis internodes $2.7-4.0 \mathrm{~mm}$.

\section{Subvarietates}

1. Trifurcatum S e r. Awns replaced by hoods.

2. Macrolepis A. B r. Glumes very broad, at least as long as the grains.

3. Inerme. Awnless ears.

4. Nudum. Naked grains.

5. Nigrum. Black or dark blue grains.

6. Laeve. Smooth awned.

In addition, according to the morphology of the rachilla at least seven different types were presented.

The genetic variation of certain grain, ear and agronomic characteristics is presented in Tables 2 and 3. In general, the values of ear and internode length were higher in the fourrow type than in the six-row type. Also the thousand seed weight was somewhat higher, As for the agronomic characteristics, landraces from the two northern provinces were the earliest. They were relatively short with a rather stiff straw but their tillering ability was lowest.

In addition to variation between the different seed lots collected there was great variation also within the lots. Consequently, the following step was to make single plant selections by which most of the characteristics could be improved.

In spite of the great variation it was impossible to find a lot with all the desirable characteristics. The most desirable characteristics of the landraces were earliness and good adaptability to acid soils. Conversely, straw stiffness and grain quality quite seldom reached acceptable levels. However, through single plant selection, a total of eight varieties were developed (Sauli 1925, 1930, Kivi 1980a):

\begin{tabular}{lcc}
\hline Variety & Two/six-row & Year of release \\
\hline Piikkiö & two & 1922 \\
Uurainen & two & 1922 \\
Halikko & two & 1924 \\
Lappi & four & 1924 \\
Halikko II & two & 1925 \\
Olli & six & 1927 \\
Perttu & four & 1929 \\
Lappi II & four & 1930 \\
\hline
\end{tabular}


Table 2. The ranges of variation of certain morphological characteristics in four-row and six-row material (SAULI 1927).

\begin{tabular}{lcc}
\hline Characteristic & four-row & six-row \\
\hline Internode length, mm & $2.98-3.58$ & $1.95-2.53$ \\
Length of ear, mm & $52.0-75.1$ & $36.9-54.7$ \\
Thousand seed weight, g & $37.9-48.8$ & $36.6-45.8$ \\
\hline
\end{tabular}

The most important of these was Olli $(0283)$ which conquered a remarkable acreage during the following two decades after it was released in 1927.

\section{Varieties originating from crosses}

The eight six-row (or four-row) varieties released since the varieties developed from landraces are presented in brief. Their pedigrees are shown in Figure 1. Also the Barley Register (BAum et al. 1981, 1985) has been used as a source of pedigrees. The agronomic characteristics are presented in Figures $2 \mathrm{a}-\mathrm{d}$.

Very soon the natural genetic variation was utilized and, similarly to other countries, the next step was to cross varieties selected from landraces. Besides these, also foreign varieties, mainly from Sweden, were used.

The first variety originating from a cross was Tammi (05049) released in 1938 (VALLE et al. 1938, Kıvı 1955b). It originated from a cross between the extremely early Olli and the late Swedish variety Asplund. Asplund is a progener of a Swedish landrace. In trials conducted in 1933 - 37 Asplund was eight days later than Tammi. In spite of its earliness - it is only two days later than Olli - Tammi outyielded both of its parents, Olli and Asplund, by 14 and $6.5 \%$ respectively. It outyielded even the acid resistant Vega, which is two days later, by $9 \%$. Consequently, it is an excellent combination of earliness and high yield. Tammi has also a much stiffer straw than Olli and Vega.

Fourteen years after Tammi, a new fourrow variety, Pirkka (Ta 04459), was released in 1952 (BRUMmer 1950, Kivi 1955b, 1955c, 1968). It is a cross between two breeding lines, the first of them originating from the Norwegian Maskin and a Finnish landrace and the latter from Olli and a Manchurian landrace. Pirkka is extremely resistant to soil acidity and possesses good malting quality. It is also a relatively early variety, maturing 3-4 days later than Tammi, but is not as high yielding as Tammi on average. However, in central parts of Finland where soil acidity is a limiting factor for barley production, Pirkka has clearly outyielded Tammi. Pirkka has also been superior in yielding capacity and straw stiffness to Vega, the Swedish acid resistant variety (KIVI 1955c).

The six-row Otra (Ta 08098) originates from a cross between Tammi and Edda (KIVI 1960). The two parents of the Swedish varieties Edda, Asplund and Vega originate from landraces from northern Sweden (HAGBERG and Persson 1962). Thus it represents the third generation after landraces. Otra is an early variety, only one day later than Tammi, with a straw stiffness equal to that of Tammi. The most remarkable improvement compared to Tammi was the yielding ability.

Table 3. The ranges of variation of agronomic characteristics of four-row landraces collected from different provinces (SAULI 1927). Provinces presented in order, from the north to the south.

\begin{tabular}{|c|c|c|c|c|c|}
\hline Province & & $\begin{array}{l}\text { Days to } \\
\text { maturity }\end{array}$ & $\begin{array}{c}\text { Tillers/ } \\
\text { plant }\end{array}$ & $\begin{array}{c}\text { Straw } \\
\text { length } \\
\mathrm{cm}\end{array}$ & $\begin{array}{c}\text { Straw } \\
\text { stiffness } \\
\text { scale } 1-10\end{array}$ \\
\hline Oulu & $\mathrm{N}$ & $94-92$ & $1.4-2.4$ & $60-103$ & $5-9$ \\
\hline Vaasa & & $87-95$ & $1.4-2.1$ & $78-97$ & $6-10$ \\
\hline Kuopio \& Mikkeli & & $90-94$ & $1.9-3.0$ & $74-97$ & $5-9$ \\
\hline Viipuri & & $89-92$ & $1.6-2.5$ & $75-86$ & $5-9$ \\
\hline Häme & $\mathrm{S}$ & $92-95$ & $1.8-2.8$ & $73-97$ & $6-7$ \\
\hline
\end{tabular}




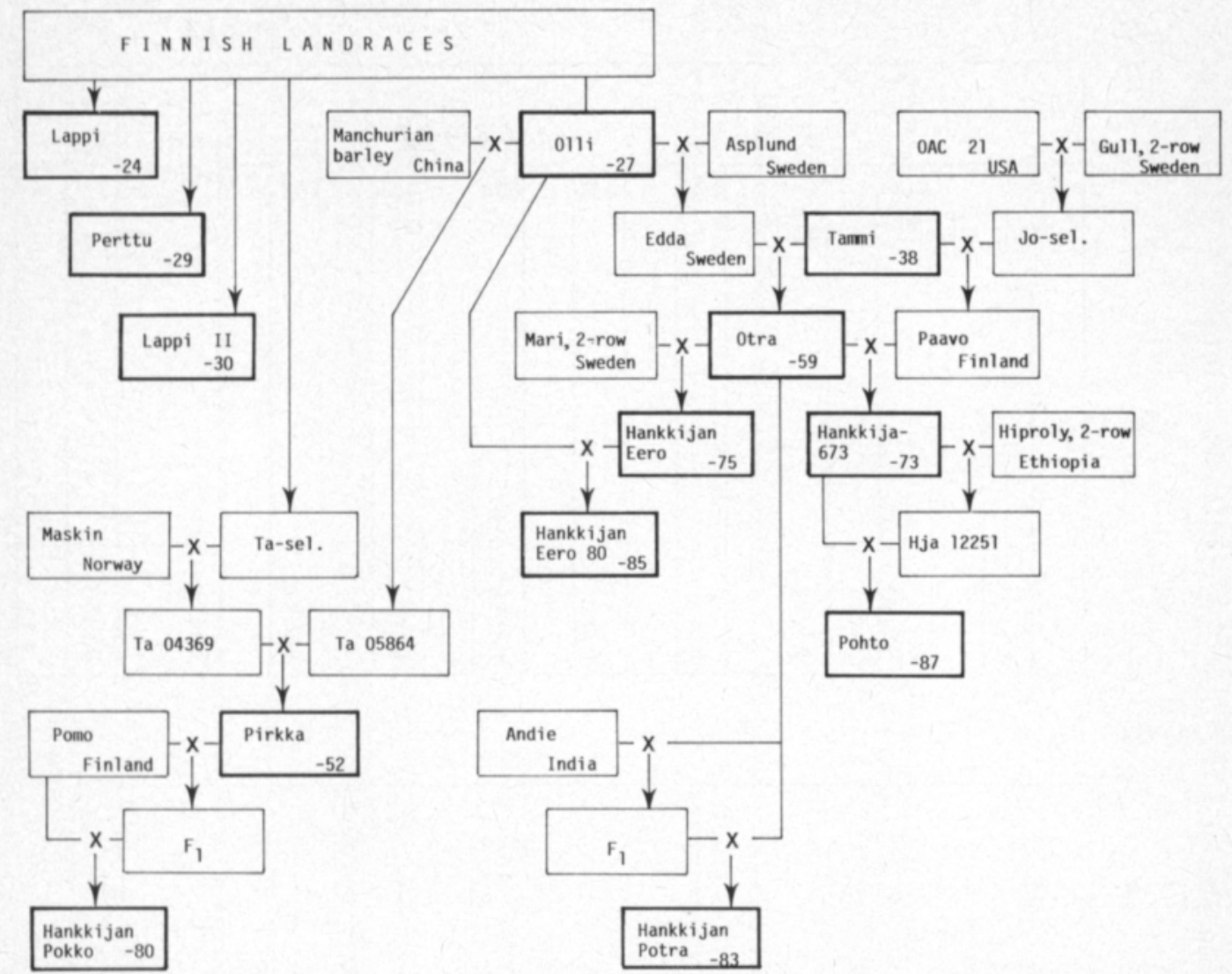

Fig. 1. Genetic origin of Hankkija's six-row varieties. Year of release or country of origin (foreign varieties) is indicated after the variety name. The codes $\mathrm{Ta}$ and $\mathrm{Hja}$ refer to Hankkija selections, Jo to The State Agricultural Research Center. Based on information published by J.O. Sauli, E. Huttunen, E. Kivi, M. Rekunen, O. Pohjanheimo, R. Manner and K. Multamàki \& A. Kaseva.

Although the trials at Tammisto Experimental Farm showed only a $5 \%$ difference for Otra compared to Tammi, the difference according to local trials all over the country was $8-11 \%$ (KIVI 1960). Although Otra rather readily adapts to different soils, it is not as acid resistant as Pirkka.

Fourteen years after Otra, a new six-row variety was developed. The previous variety Otra was crossed in 1954 with Paavo, which was released by The State Agricultural Research Center in 1960 (MULTAMÄKı and KASEva 1983), resulting in the variety Hankkija-673 (Hja 32661) (REKUNEN and KIVI 1975). Consequently, new genes had been introduced to Finnish breeding material because Paavo includes the Swedish two-row Gull and the American six-row OAC 21 in its pedigree. Hankkija-673 is only one day later than Otra, but has a shorter and slightly stiffer straw. As to grain yield, trials in southern Finland have shown a $5 \%$ difference for Hankkija-673.

The six-row Hankkijan Eero (Hja 34715), released in 1975, is a result of a new breeding system originating from a cross between the Swedish variety Mari and the six-row Otra (REKUNEN and Kivi 1975b). Mari is an early two-row, $\mathrm{ea}^{8}$ mutant from Bonus (HAGBerG and Persson 1962). It is insensitive to daylength, being the earlier the farther south it is grown. The purpose has been to combine two different genes of earliness into one genotype (KIVI 1977). Eero is an extremely early variety but only in short daylength conditions. 


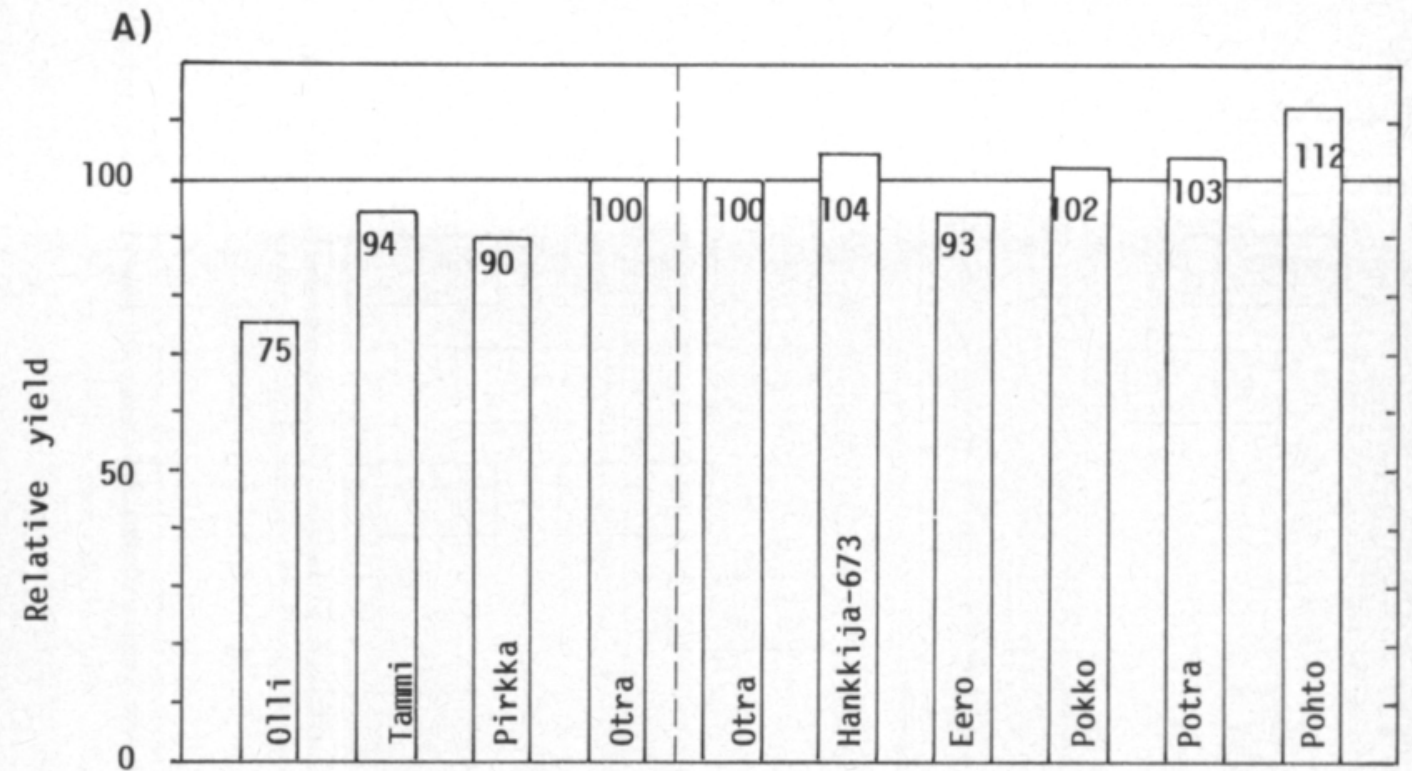

B)

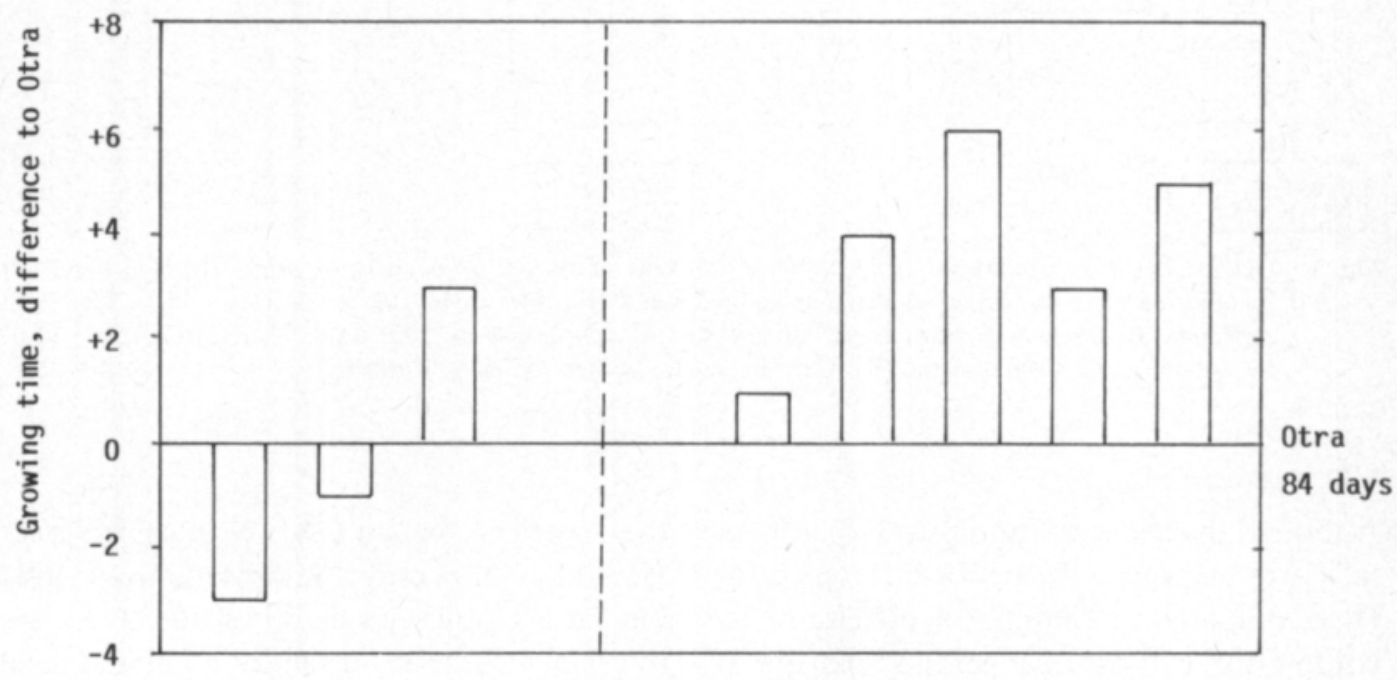

It has inherited Mari's reaction to daylength and is 10 days later than Otra in northern Finland (approx. 66th parallel) compared with a difference of about three days in the south.

As to other characteristics, Eero is a transgressive variety for shortness and stiffness of straw which was a drastic improvement compared to previous varieties. Originating from a cross between two-row and six-row types Eero has high growth requirements. This means that the high yielding potential based on its good tillering capacity can be utilized only in optimal growing conditions.

The genetic yielding potential of six-row barley can be increased by increasing its tillering capacity by crossing it with a two-row type (TAKAHASH et al. 1975). Hankkijan Eero is an excellent example of this method. Another argument for crossing six-row barley with the two-row type is to increase the straw stiffness of the former type. During the 1970s, a great number of this kind of crossings were made 
C)

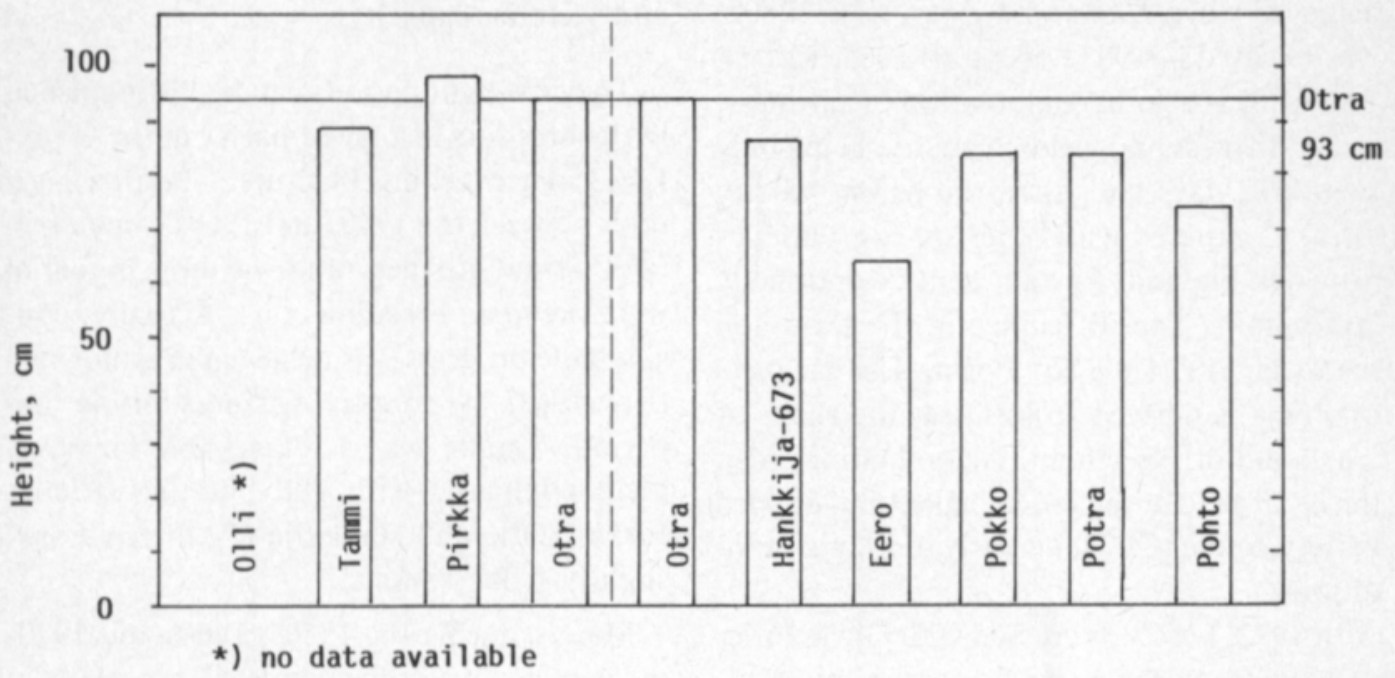

D)

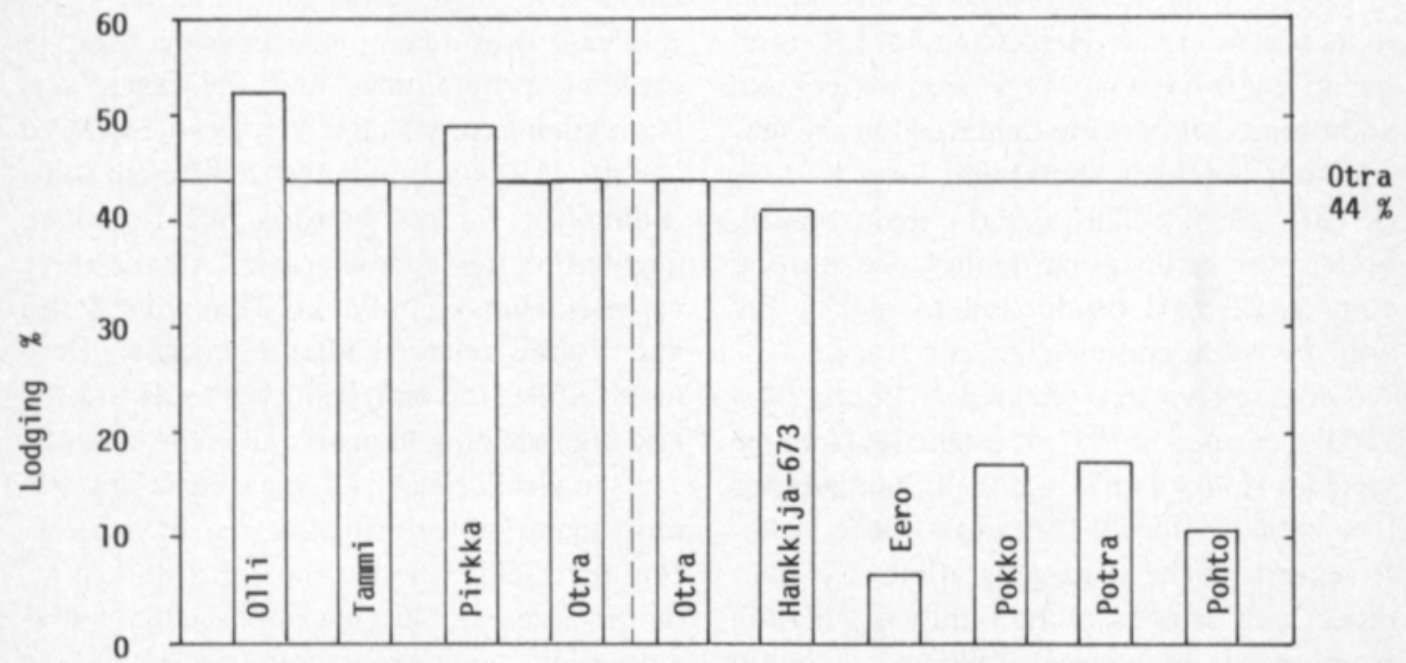

Fig. 2. Relative yield (a), difference in growing time (b), plant height (c) and straw stiffness (d) of varieties compared to the long-term standard variety Otra based on the official trials during 1977-86 (varieties released after Otra) and on the main cultivar trials at Tammisto before 1955 (varieties released before Otra).

(KIVI 1980b).

The variety Hankkijan Pokko (Hja 70352), released in 1980 (REKUNEN and KIVI 1980, AIKASALO 1985), also includes genes from the two-row type in its pedigree. It originates from the varieties Pomo and Pirkka of which the former is a cross between the six-row and tworow types. During the time of release, Pokko was ranked among the highest yielding varie- ties. Pokko is six days later than the long term standard variety Otra, being, however, suitable for cultivation even in central Finland. The influence of the two-row component can be seen also in the good straw stiffness compared to previous varieties except for Hankkijan Eero.

All the previous early varieties had too weak a straw for modern intensive barley produc- 
tion. A considerable improvement was achieved when Hankkijan Potra (Hja 72802) was released in 1983 (AiKasAlo 1985, KesÄLÄ 1985b). It is a good combination of earliness, straw stiffness and yielding ability, being only two-three days later than the parent variety Otra. Compared with other six-row varieties grown in Finland, Potra has an exceptionally large grain. The difference in the thousand seed weight is $4.8 \mathrm{~g}$ for Potra. The earliness of Potra is derived from Otra, the share of which in Potra's genome is dominating. Also the other parent, the Indian naked and hooded variety Andie (CI 728) is early in Finnish conditions.

In 1972, Eero was crossed with Olli in order to enhance earliness and adaptability. This programme resulted in the selection $\mathrm{Hja} 77061$ which was given the name Hankkijan Eero 80 in 1985, because it is morphologically similar to its parent variety Hankkijan Eero. Consequently, it is not a new registered variety. No additional earliness was achieved but the new selection outyields Hankkijan Eero by $6 \%$ (KesÃla 1985a). This was the main reason, besides the better grain quality, for starting commercial seed production to replace the "old Eero" in commercial seed trade.

The latest variety released is Pohto $(\mathrm{Hja}$ 78003), released in 1987 . It originates from the varieties Hankkija-673 and the Ethiopian tworow variety Hiproly (AIKASAlo 1987, 1988). It represents the fifth generation after landraces and belongs to the family originating from the cross between Olli and Asplund made in 1926.

Pohto is not a very early variety. It is four days later than the parent variety Hankkija-673, possibly due to the influence of the two-row Hiproly in the pedigree. Pohto combines the high yielding potential of Hankkija-673 and the straw stiffness and good tillering capacity of the two-row parent. Today it is clearly the highest yielding variety in Finland (REKUNEN 1987). In spite of the high-lysine variety Hiproly in its pedigree Pohto has only a medium protein content and normal protein quality.

\section{Development of earliness, lodging resistance and yielding capacity}

Two different periods can be distinguished in the breeding history of barley at the Hankkija Plant Breeding Institute. The first period is between the 1910s and 1960s when earliness, straw stiffness and yielding potential were the main breeding aims. Actually, considerable progress was achieved in grain yield (KIvi 1963). As to straw stiffness during that period, Tammi was a remarkable improvement compared with Olli but the varieties Pirkka, Otra and Hankkija-673 differed only slightly from Tammi.

Mainly during the 1950 s, 1960 s and 1970 s the increase in fertilization level, especially in the use of nitrogen, as well as the introduction of combine harvesting emphasized the demand for stiff strawed varieties. This challenge was taken into consideration in breeding programmes and the result was Hankkijan Eero which is a really stiff strawed variety. It is poorly adapted to different soils, calling for further breeding efforts to be devoted to this characteristic. All the three varieties, Hankkijan Pokko, Hankkijan Potra and Pohto, released after Hankkijan Eero have fulfilled this aim, being both stiff strawed and high yielding in nearly all environments.

As to yielding capacity, the genetic gain was most remarkable during the first 40 years before the $1960 \mathrm{~s}$, whereas the improvement after the release of Otra has not been as remarkable as in many other countries (AIKASALO and KarJalainen 1986). On the contrary, the better straw characteristics of varieties released since the mid-1970s have enabled farmers to use higher amounts of nitrogen, which has resulted in a considerable increase in total barley production without loosing reliability. Trial results during the $1980 \mathrm{~s}$ indicate, however, that gains in grain yield are forthcoming. The best breeding lines, including the latest variety Pohto, outyield the previous varieties by 10-15\% (AikASAlo and Kesälä 1985).

It is worth noticing that the earliness of 
landraces could not be exceeded. On the contrary, the latest varieties are several days later than e.g. Olli, the extremely early variety originating from a landrace. Consequently, breeding for higher yielding capacity as well as the use of two-row genotypes in breeding programmes has resulted in the loss of some of the earliness.

\section{Results of breeding for malting quality}

Most of the barley produced in Finland is used for feeding purposes. Today, only $6-7$ $\%$ is used for malting. However, even during the first decades of this century malting characteristics were included in the breeding aims (VAlle et al. 1938). The Finnish six-row malting varieties are characterized by high enzyme activity which can be utilized especially in the production of enzyme malts used in the production of distilled drinks.

The first variety which was used for malting was six-row Olli. Although it originated from a landrace, the quality of grain was good enough to satisfy the requirements of malting industry at that time. It was classified as a malting variety in Canada (MALAHER 1961) although the domestic malting industry used only the two-row varieties Binder and Balder as raw material.

Twenty-five years after Olli a new malting variety, Pirkka, was released. Pirkka originates from a cross between two breeding lines of which the male parent includes Olli and Manchurian barley in the pedigree. Pirk$\mathrm{ka}$ is of the four-row type with a long, nodding ear. The internodes are long. This type of barley was considered to be the most suitable for malting (WIEBE and REID 1961). The kernels are large and plump, exceeding even the level of the later varieties Pomo and Hankkijan Pokko (Table 4). Pirkka is internationally probably the most famous Finnish variety because of its high enzyme activity, and it has often been subjected to studies on the enzymes of barley (SMIRNOVA-IKonNiKova and Petrova 1964, Linko and Enari 1966, Kivi 1968, ENARI and LinKo 1969). In Finland,
Pirkka was the dominating enzyme malt variety from the 1950 s to 1970 s.

The latest malting variety is Hankkijan Pokko. In addition to its use as an enzyme malt variety it has been accepted for brewing purposes. The kernels are not as large and plump as those of Pirkka but the enzyme activity, especially $\alpha$-amylase, is higher than in either parent (Table 4). Because of the superior agronomic characteristics compared with Pirkka, Pokko has been the predominating enzyme malt variety in Finland during the 1980s.

\section{The significance of Hankkija varieties on barley cultivation in Finland}

Before commercial varieties were developed, landraces were grown. In the 1910s, however, the first varieties had spread to Finland. They were foreign, mainly Swedish varieties. The most important were the two-row Svanhals, Primus and Gull, the four-row Vega as well as the six-row Asplund and the Danish two-row Binder (PaAtela 1953). Along with these as well as with the first domestic varieties developed during the 1920 s, the acreage of landraces began to decrease.

The first important domestic variety was Olli, followed by Tammi at the end of the 1930 s. There is no exact information available about the acreage of Olli, but Olli's proportion of the samples collected by the State Seed Testing Station in 1935 was $10 \%$. Since the early 1940s, Tammi started to replace Olli and reached its maximum acreage around 1955 (Fig. 3). It was grown main-

Table 4. Certain quality characteristics of Finnish enzyme malt varieties (Home 1979).

\begin{tabular}{llll}
\hline & Pirkka & Pomo & Pokko \\
\hline Protein \% & 13.1 & 12.4 & 11.9 \\
Grading $>2.5 \mathrm{~mm}$ & 86.5 & 84.0 & 80.5 \\
Extract \% & 79.4 & 79.0 & 80.7 \\
$\alpha$-amylase, DU & 87 & 96 & 117 \\
Diastatic power, WK & 650 & 600 & 670 \\
Number of samples & $3 \times 5$ & $3 \times 9$ & $3 \times 12$ \\
\hline
\end{tabular}




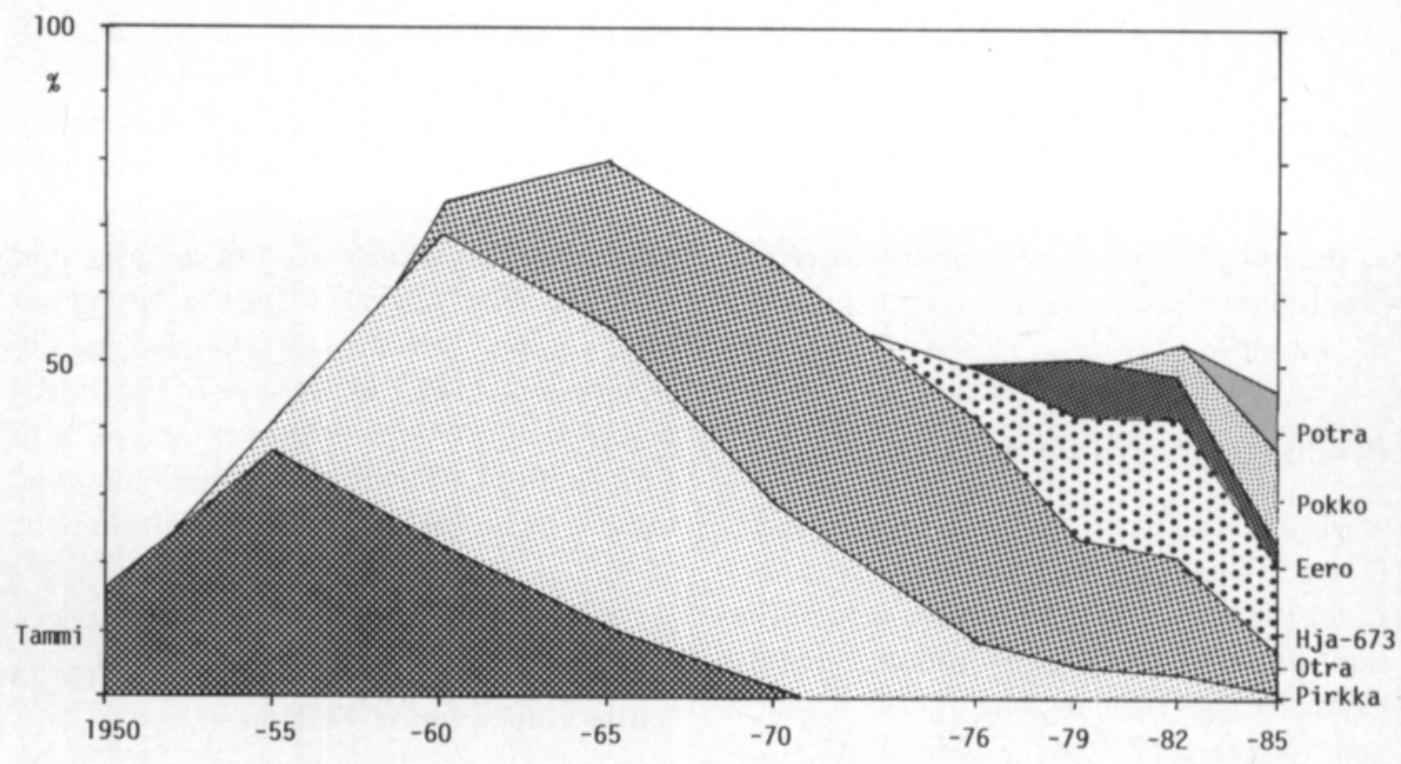

Fig. 3. Proportion of Hankkija's six-row varieties of the total barley acreage in Finland since 1950 (Official Statistics of Agriculture).

ly in central and northern parts of the country, whereas the Danish two-row Binder and the Swedish Balder predominated in the barley production in the south (PAATELA 1953).

Since the mid-1950s, Pirkka has been replacing Tammi. The most important advantage of Pirkka over Tammi was the extremely good resistance to soil acidity, wherefore it replaced also the Swedish acid resistant Vega. In 1950, Vega still covered more than $20 \%$ of the total barley acreage.

Otra and Hankkija-673 continued the sequence of early varieties, conquering a remarkable growing area, the former for more than 20 years and the latter for more than 10 years. Both of them are still grown to some extent in central and northern parts of the country.

Varieties released since the mid-1970s have not covered as large an area as many earlier ones. Firstly, continuous draining and liming of fields have resulted in improved soil conditions, making it possible to grow more tworow varieties with high soil requirements. The Swedish variety Kustaa (Svalöf 1979) is a good example covering approx. $20 \%$ of the barley acreage since the mid-1980s. Secondly, the to- tal number of barley varieties grown in Finland has increased during the last 10 years, resulting in a smaller acreage per variety. Still in 1985, Hankkija's six-row varieties covered nearly $50 \%$ of the total barley acreage.

\section{Utilization of Hankkija varieties in other countries}

There are several examples of utilization, either in crossings or in barley production, of Hankkija varieties in other countries. The main reason for this utilization has been the earliness.

Olli has been used as a parent variety for the Canadian malting barley Gateway (WIEBE and REID 1961). Furthermore, Olli itself (a single plant selection from Olli) has been grown extensively in some provinces of Canada, especially in central and northern Alberta and Saskatchewan (WIEBE and REID 1961, GuITARD et al. 1965). In these regions earliness is a prerequisite for cereal production (GuITARD 1960). The climate is characterized by a short growing season, monthly temperatures averaging $10-16^{\circ} \mathrm{C}$ in May to September. In 1960, Olli covered an acreage of more 
than 1.0 million hectares in Alberta (MALAHER 1961). Even in the 1980s Olli has been included among the early varieties recommended to be grown in certain provinces of Canada.

Both Olli and Hankkijan Eero, which is insensitive to daylength, have been used as a source of earliness in the breeding programmes of the CIMMYT institute (ANON. 1978).

Similarly, the earliness of Tammi has been transferred to the extremely early Swedish two-row variety Arla (Hörberg 1964).

Two varieties, Pirkka and Otra, have been grown quite extensively in the Soviet Union. The success of these varieties in northwestern parts of the country can be explained not only by their earliness but also by their good adaptation to acid soils and extensive cultivation with low level of fertilization (DENISOva 1961). During the 1970s and 1980s, Otra has been the most popular barley variety in Estonia (LEPAJOE 1986).

\section{Conclusion}

Due to the short growing season earliness has always been a major breeding aim in Finland together with straw stiffness, wide adaptation and yielding potential. Landraces have been of considerable value as a source of both earliness and adaptation. They were used as the basic breeding material when scientific barley breeding started in the early 20th century. A total of eight varieties were developed from them, Olli being the most important.

Thereafter breeding continued by crossing the already developed domestic varieties with new foreign ones. The varieties developed all have the extremely early $\mathrm{Olli}$ - more or less - in their pedigree, with as many as five of them belonging to the same family. Thus Olli has had a very dominant influence in the breeding of six-row barley. The pedigree chart (Fig. 1) illustrates clearly that breeding has been based on a rather narrow gene pool. All the eight varieties are mostly based on Scandinavian varieties. Only a few gene sources outside Scandinavia have been introduced to breeding programmes. Nevertheless, breeding has resulted in several productive varieties which have conquered a remarkable acreage.

There are excellent examples of the use of local germ plasm as the main gene source in other countries, too (WYCH and RASMUSSON 1983, WIBERG et al. 1986), which suggests that there is substantial opportunity for genetic gain within a narrow germ plasm base. WYCH and RASMUSSON (1983) have also pointed out that judging germ plasm diversity on the basis of pedigrees is speculative and that considerable useful genetic diversity may exist within what is assumed to be a narrow gene pool.

The earliness of landraces or the extremely early Olli has not been exceeded. Breeding for yield capacity and straw stiffness has occurred at least partly at the expense of earliness, especially after the 1960 s. Considerable progress in genetic yield potential has been achieved since the landraces. It was previously shown by KIVı (1963), using five-year periods, that in 1925-1957 barley breeding in Finland accounted for $9 \%$ of the total increase in yield (37 \%) for six-row barleys. The largest and steadiest increase in yield occurred between the late 1940 s and early 1960 s when Otra replaced Tammi, the most productive cultivar in previous decades. The rate of increase during those five-year periods ranges from $3.7 \%$ to $5.5 \%$. Thereafter the genetic yield improvement has been less remarkable than in many other countries (Aikasalo \& KarJalainen 1986). However, during this decade it seems that a genetic gain in yield is possible, the latest breeding lines being approx. $10-15 \%$ higher yielding than the varieties released at the turn of the 1970s and 1980s (AIKASAlo \& KESÄLÄ 1985).

Considerable improvement in other characteristics, especially in straw stiffness but also in malting quality, has been achieved too. 


\section{References}

Aikasalo, R. 1985. New six-row varieties. Hankkijan Pokko, Hankkijan Potra. Barley Newsletter 28: 76-77.

- 1987. Barley. New selections and breeding prospects 1987: 8-9. Hankkija Plant Breeding Institute.

- 1988. New six-row varieties. Pohto. Barley Newsletter 31. (in press).

— \& Kesälä, P. 1985. Ohra. Hankk. Siemenjulkaisu 1985: 54-72.

— \& Karjalainen, R. 1986. Genetic yield improvement of spring barley under marginal growing conditions in Finland. Proc. Fifth Intern. Barley Genet. Symp. 1986, Okayama. (in press).

Anon. 1978. Barley. Cimmyt Review 1978: 84-90.

- 1910-1985. Off. Agric. Statist., Board of Agric. Helsinki.

Baum, B.R., Thompson, B.K., Balley, L.G. \& Brown, M. 1981. Barley Register. First Report. Research Branch, Agriculture Canada.

-, Balley, L.G. \& Thompson, B.K. 1985. Barley Register. Agriculture Canada, Publ. 1783 B.

Brummer, V. 1950. Ohra. Summary: Barley. Hankk. Siemenjulkaisu 1950, 1: 38-47.

Denisova, P.V. 1961. Recommended varieties for Leningrad district. (in Russian).

ENARI, T-M. 1969 \& LinKo, M. 1966. Significance of barley and malt amylases. Ann. Agric. Fenn. 8: 149-156.

Grotenfelt, G. 1919. Suomalainen peltokasviviljelys II. 517 p. Helsinki.

GuitARD, A.A. 1960. The influence of variety, temperature and stage of growth on the response of spring barley to photoperiod. Can. J. Plant Sci. 40: 65-80.

-, Taylor, R.L., Brinsmade, J.C., Gilbey, J.A., New. Man, J.A. \& Tsukamoto, J.Y. 1965. Growth of spring cereals in northwestern Canada and Alaska. Canada Dept. Agric. 1220: 1-11.

Hagberg, A. \& Persson, G. 1962. Svalöfs kornsorter. Summary: The Svalöf barley varieties. Sver. Utsädesf. Tidskr. 72: 337-351.

Hoffmann, W. \& Plarre, W. 1970. Gerste. Lehrbuch der Züchtung landwirtschaftlicher Kulturpflanzen 2: 37-71. Berlin und Hamburg.

Номе, S. 1979. Biotekniikan laboratorion tutkimustuloksia. Mimeogr. (Available at Biotechn. Lab. of the State Techn. Res. Center, Helsinki, Finland).

HUtTUNEN, E. 1955. Tammiston kasvinjalostustoiminnan historiikkia v. 1913-1954. Hankk. Siemenjulkaisu 1955: 180-202.

Horberg, Y. 1964. Weibulls original Arlakorn. Ny, mycket tidig 2-radssort. Weibulls årsbok för vãxtförãdling och växtodling 59: 8-13.

KesĀlA, P. 1985a. Hankkijan Eero -ohran uusi valio. Hankk. Siemenjulkaisu 1985: 174-177.

- 1985b. Hankkijan Potra -ohra. Hankk. Siemenjulkaisu 1985: 153-155.
Kıvı, E. 1955a. Ohra. Summary: Barley. Hankk. Siemenjulkaisu 1955: 35-43.

- 1955b. Ohranjalostus Tammistossa. Summary: Barley breeding at Tammisto. Hankk. Siemenjulkaisu 1955: 123-133.

- 1955c. Pirkkaohra. Summary: Pirkka barley. Hankk. Siemenjulkaisu 1955: 115-118.

- 1960. Otraohra. Summary: Otra barley. Hankk. Siemenjulkaisu 1960: 194-198.

- 1963. Domestic plant breeding for the improvement of spring cereal varieties in Finland. A review based on the activity of The Plant Breeding Institute of Hankkija. Selostus: Kotimainen kasvinjalostus kevätviljain lajiketason kohottajana. Suom. Maatal. tiet. Seur. Julk. 100, 3: 1-37.

-1966 . The response of certain pre-harvesting climatic factors on sensitivity to sprouting in the ear of tworow barley. Acta Agr. Fenn. 107: 228-246.

- 1968. Pirkka - a high enzyme six-rowed barley. Peat \& Plant News 1, 1: 12-15.

- 1978. Short season barley breeding. Fourth Intern. Winter Cereal Workshop. Amman, Jordan. p. 109-118.

- 1980a. Hankkijan kasvinjalostuslaitoksen lajikkeet 1919-1980. Summary: List of varieties released by The Hankkija Plant Breeding Institute from 1919-1980. Hankk. Siemenjulkaisu 1980: 158-162.

- 1980b. Ohra. Hankk. Siemenjulkaisu 1980: 40-52.

Lepajoe, J. 1986. Oder. Tallin, Valgus. 152 p.

LinKo, M. \& EnARI, T-M. 1966. High Amylolytic Activities in Barley Malt. Brewer \& Distiller 1, 1: 1-12.

Malaher, W.G. 1961. Malting Barley in Western Canada. Searle Grain Company Ltd. Winnipeg, Manitoba. $31 \mathrm{p}$.

Multamăkı, K. \& Kaseva, A. 1987. Domestic varieties. The State Agric. Res. Center, Comm. 11/1987.

PaAtela, J. 1953. Tärkeimmät viljalajikkeemme ja niiden viljelyalueet. Summary: The Most Important Varieties of Cereals Grown in Finland and their Growing Areas. Suom. Maatal. tiet. Seur. Julk. 80, 1: 1-78.

Pesol.A, V.A. 1951. Lantstråsådes- och ärtsorternas tidigare och nutida utbredning i Finland, deras egenskaper och betydelse för växtförädlingen samt tillvaratagningen av desamma. Maatal. tiet. Aikak. 23: 193-210.

Rekunen, M. 1987. Satoisa ja lujakortinen Pohto-ohra tulee myyntiin. Kylvösiemen 1987, 2: 23-25.

— \& Kıvı, E. 1975a. Monitahoinen ohra Hankkija-673. Summary: The six-rowed barley Hankkija-673. Hankk. Siemenjulkaisu 1975: 143-148.

— \& Kıvı, E. 1975b. Hankkijan Eero -ohra. Summary: Hankkija's Eero barley. Hankk. Siemenjulkaisu 1975: $148-152$.

— \& Kıvı, E. 1980. Hankkijan Pokko -ohra. Summary: Hankkija's Pokko barley. Hankk. Siemenjulkaisu 1980: $121-124$. 
SAUL, J.O. 1925. Kertomus Hankkijan kasvinjalostuslaitoksen toiminnasta vv. 1921-1924. Hankk. Siemenjulkaisu 1925: 18-29.

- 1927. Suomen maatiaisohrat ja niiden jalostusarvo. Referat: Die Finnischen Landgersten und ihr züchterischer Wert. Suom. Maatal.tiet. Seur. Julk. 16. 139 p. Helsinki.

- 1930. Selostus Tammiston uusimmista kauppaanlasketuista jalosteista. Hankk. Siemenjulkaisu 1930: $180-183$.

Smirnova-Ikonnikova, M.I. \& Petrova, T.M. 1964. Amylolytic and proteolytic activity of enzymes in the grain and malt of malting varieties of barley. Vestn Selskhoz Nauk 12: 64-69.

Takahashi, R., Hayashi, J. \& Moriya, I. 1975. Basic Studies on Breeding Barley by the Use of Two-Rowed and Six-Rowed Varietal Crosses. Proc. Third Intern. Barley Genet. Symp. Carching. p. 662-677.

Valle, O., Huttunen, E. \& Rancken, G. 1938. Tuloksia vertailevista laatukokeista Tammistossa 1935 - 1937.

\section{SELOSTUS}

\section{Monitahoisen ohran jalostus ja lajikkeiden perinnöllinen tausta}

\section{Reino Aikasalo \\ Hankkijan kasvinjalostuslaitos 04300 Hyrylä}

Lyhyestä kasvukaudestamme johtuen aikaisuus on aina ollut keskeinen jalostustavoite korrenlujuuden, viihtyvyyden ja sadontuottokyvyn ohella. Monitahoinen ohra on aikainen kasvilaji, jonka jalostustyöstä Hankkijan kasvinjalostuslaitoksella vuodesta 1913 kerrotaan tässä artikkelissa.

Aikaiset maatiaisohrat, jotka sisälsivăt runsaasti muuntelua, muodostivat jalostustyön lähtökohdan vuosisadan alussa. Valintajalostuksen tuloksena laskettiin kauppaan yhteensä 8 jalostetta, joista 4 oli monitahoista. Näistä merkittăvimmäksi muodostui erittäin aikainen Olli.

Valintajalostusvaiheen jälkeen myös risteytysjalostuksen tuloksena on laskettu kauppaan kahdeksan lajiketta, joiden jokaisen perimäăn sisăltyy Ollin geenistỏă, ja joista 5 kuuluu samaan sukuun. Useimmat lajikkeet polveutuvat pảảosin Skandinaviasta peräisin olevista lajikkeista, vain muutamia kaukaisia lajikkeita on sisällytetty jalostusohjelmiin. Siitả huolimatta jalostustyő on tuottanut lukuisia menestyksekkäită lajikkeita, joista jokaisesta on lyhyt kuvaus.
Referat: Ergebnisse vergleichender Sortversuche auf Tammisto 1935-37. Hankk. Siemenjulkaisu 1938: 53-106.

Wiberg, A., Halling, S. \& RuUth, P. 1986. Breeding for marginal northern areas. Svalöf 1886-1986. Research and results in plant breeding. (Ed. by G. Olsson). p. 252-263. Stockholm.

Wiebe, G.A. \& ReID, D.A. 1961. Classification of barley varieties grown in The United States and Canada in 1958. United States Dept. of Agric., Techn. Bull. 1224. 234 p.

WyCh, R.D. \& Rasmusson, D.C. 1983. Genetic improvement in malting barley cultivars since 1920. Crop Sci. 23: $1037-1040$.

ÄYräväınEN, K. 1976. Yield composition of two-rowed and multi-rowed barleys in drilled and single plant populations in southern and northern Finnish experiments. J. Agric. Sci. Finl. 48: 13-31.

Ms received 1988
Jalostustyön tuloksena ei ole pystytty kehittămaaăn Ollia aikaisempia lajikkeita. Päinvastoin, satoisuuden ja korrenlujuuden parantaminen perustuen kaksitahoisen ohran perimän käyttöön risteytysohjelmissa on johtanut kasvuajan pidentymiseen. Satoisuus on jalostustyön tuloksena parantunut huomattavasti maatiaisten tasosta. Sadonnousu on ollut voimakkainta 1940-, 1950- ja 1960-luvuilla keskimäăräisen viisivuotiskauden nousun ollessa 4-5\%. 1970- ja 1980-luvun alun lajikkeet ovat vain lievästi satoisampia kuin Otra. Kuluvan vuosikymmenen tulokset osoittavat kuitenkin, ettă lähiajan uudet lajikkeet tulevat olemaan $10-15 \%$ Otraa satoisampia.

Satoisuuden ohella myös muita ominaisuuksia, erityisesti korrenlujuutta, on pystytty parantamaan huomattavasti. Tämă on mahdollistanut aikaisempaa voimaperăisemmän viljelyn ja viljelyalan kasvun myötă ohran kokonaistuotannon nousun nykyiselle, lähes kahden miljardin kilon tasolle vuodessa.

Eraaită lajikkeita on sekä hyödynnetty jalostustyössă aikaisuuslähteenä että viljelty muissa maissa, mm. Kanadassa ja Neuvostoliitossa. 